\title{
Virtuel 3D simulering vs. traditionel anatomiundervisning
}

\section{En kvantitativ sammenligning af læringsudbytte}

\author{
Michael Ehrnberg Fravn, Professionshøjskolen UCN \\ Jens Kristian Vejle-Sørensen, Professionshøjskolen UCN \\ Lars-Göran Zetterberg, Professionshøjskolen UCN
}

\begin{abstract}
Fremskridt inden for IT-baseret medicinsk billedrekonstruktion har gjort billedbehandling i såvel 2D som 3D til en vigtig del af billeddiagnostikken. Dette stiller særlige krav til faggrupper som f.eks. radiografer. I dette projekt har vi kvantitativt målt radiografstuderendes læring af 3D-anatomi ved virtuel 3D simulering på Sectra Table og sammenlignet denne med læringsudbyttet ved traditionel anatomiundervisning. To kohorter radiografstuderende udgiorde studiepopulationen. 1. kohorte gennemgik et undervisningsforløb baseret på simulering i 3D. 2. kohorte gennemgik et forløb af tilsvarende længde med traditionel holdundervisning. De studerendes viden om 3D-anatomi blev testet før og efter intervention. Ændringer i testresultater sammenlignedes mellem de to kohorter. Studiet har ikke påvist statistisk signifikante forskelle i radiografstuderendes læringsudbytte af 3Danatomi mellem de to undervisningsmetoder. Undersøgelsens resultater tyder dog på, at Sectra Table kan være et udmærket supplement til traditionel holdundervisning, når hensigten er, at radiografstuderende skal lære 3D-anatomi.
\end{abstract}

\section{Engelsk abstract}

Progress in electronically supported reconstruction of medical images has made 2D and 3D imaging an important part of diagnostic imaging. This poses specific demands on groups of professionals such as radiographers. We quantitatively compared the learning outcome of virtual 3D simulation using Sectra Table and traditional anatomy teaching. The study population was two cohorts of Danish radiographer students. The first cohort completed an anatomy course based on virtual $3 \mathrm{D}$ simulation; the second cohort completed a course of similar length based on traditional anatomy teaching. The students' knowledge of $3 \mathrm{D}$ anatomy was tested before and after the intervention and changes in test results were compared. There were no statistically significant differences between learning outcomes for the two cohorts of radiographer students concerning knowledge of $3 \mathrm{D}$ anatomy. The results indicate, however, that Sectra Table can be a valuable supplement to traditional class teaching in $3 \mathrm{D}$ anatomy for radiographer students. 


\section{Baggrund}

Gode kundskaber i anatomi og fysiologi er essentielle inden for de sundhedsfaglige uddannelser for, at de studerende skal kunne forstå især naturvidenskabelige problemstillinger (Nielsen \& Springborg, 2005). Der er for en stor del tale om udenadslære, hvor studerende ved de sundhedsfaglige uddannelser blandt andet skal lære latinske betegnelser på en lang række anatomiske strukturer og kombinere denne viden med kundskaber om de forskellige organsystemers fysiologi og samspillet mellem disse.

Mellem de forskellige sundhedsfaglige professioner er der visse forskelle, i hvilke dele af fagområdet anatomi og fysiologi som er særlig relevante. Dette afspejler sig også i de forskellige sundhedsfaglige uddannelser. På Radiografuddannelsen ved University College Nordjylland (UCN Rad) prioriteres undervisningen i billedanatomi højt. Billedanatomi går ud på, at de studerende skal lære at identificere anatomiske strukturer på baggrund af et billedmateriale produceret på radiologisk, nuklearmedicinsk eller stråleterapeutisk afdeling. Undervisningen kombineres ofte med faget patologi, hvor de studerende også undervises i, hvordan forskellige sygdomme manifesterer sig på radiografisk billedmateriale. Der er typisk tale om billedmaterialer produceret ved konventionel røntgen, CT-skanning (Computed Tomography), MR- skanning (Magnetisk Resonans) og ultralydsskanning samt scintigrafier.

Igennem en længere årrække er der sket en omfattende teknisk udvikling inden for det billeddiagnostiske område. En af konsekvenserne af denne er, at en lang række undersøgelser, som tidligere blev foretaget ved konventionel røntgen og visualiseret i to dimensioner (2D), nu foretages ved forskellige skannertyper, som giver mulighed for at visualisere kroppen i forskellige planer og/eller i tre dimensioner (3D) (Lundström et al., 2011).

Indtil gennemførelsen af dette projekt har anatomiundervisningen ved simulering ved brug af Sectra Table (fig. 1) foregået uden, at vi i UCN Rad har vidst om udstyret har haft en positiv effekt på de studeres læring inden for $3 \mathrm{D}$-anatomi.

Iflg. Lundstrøm et al. er 3D-simulering et vigtigt værktøj i forbindelse med diagnosticering samt planlægning af videre behandling af patienter (Lundstrøm et al., 2011). De beskriver, hvordan Sectra Table er blevet udviklet med henblik på at udnytte $3 \mathrm{D}$-visualiseringens potentiale i forhold til at ligne den fysiske virkelighed mest mulig samtidig med, at brugerne hurtigt skal kunne lære at udnytte værktøjet. Man gennemførte også et mindre studie, hvor fem ortopædkirurger uden tidligere erfaring med Sectra Table fik en demonstration af få minutters varighed af Sectra Table's overordnede funktion samt en systematisk gennemgang af øvrige værktøjer. Efterfølgende skulle de diagnosticere samt planlægge det videre behandlingsforløb med udgangspunkt i 3D-rekonstruktioner af patienter med frakturer. Kirurgernes overordnede vurdering var, at Sectra Table var anvendeligt og fordelagtigt at bruge i det daglige arbejde (Lundstrøm et al., 2011). I artiklen kommer man dog ikke ind på Sectra Table's eventuelle potentiale i forbindelse med undervisning, men systemernes anvendelsesmuligheder og forventede fortsatte udbredelse inden for sundhedsvæsenet kan i sig selv ses som et vægtigt argument for at inddrage dem i undervisningen af f.eks. radiografstuderende. Det, at Sectra Table kunne bruges allerede efter en kort demonstration, vil selvfølgelig også være en fordel i en undervisningssituation.

Garg et al. skriver, at IT-baserede anatomiske modeller i 3D, hvor man fokuserer på et udvalgt organsystem eller et udvalgt virtuelt snit, burde have betydelige fordele $\mathrm{i}$ forbindelse med anatomiundervisning sammenlignet med de traditionelle præsentationer, man finder i anatomibøger i og med, at de studerende kan vende og dreje et udvalgt anatomiske objekt, som om det var et 3D-objekt, de havde i hænderne (Garg et al., 2002). Dog er der overraskende nok tidligere studier som indikerer, at disse fordele ikke er reelle, men noget vi forestiller os (Garg et al., 2002). Grunden til dette kunne være, at mennesker mere eller mindre ubevidst har en tendens til at rotere de rumlige informationer man får fra f.eks. en vinklet projektion til en kendt projektion i en ret vinkel, som man kender det fra f.eks. anatomibøgerne. Denne tankeproces kan medføre en yderligere mental belastning med risiko for, at fokus flyttes fra indlæring af anatomien til den tankemæssige rotation. 
Med afsæt i dette gennemførte Garg et al. et studie, hvor 87 førsteårs medicinstuderende blev delt op i randomiserede grupper (Garg et al., 2002). To af grupperne skulle lære om håndleddets anatomi ved at betragte et billedmateriale, hvor anatomien kunne roteres i forskellig grad. De blev efterfølgende sammenlignet med en tredje gruppe, som havde studeret samme håndledsmodel, men kun i to på hinanden vinkelrette planer (aksial og horisontal), hvor de dog havde mulighed for at justere projektionsvinklen nogle fă grader i forhold til disse planer.

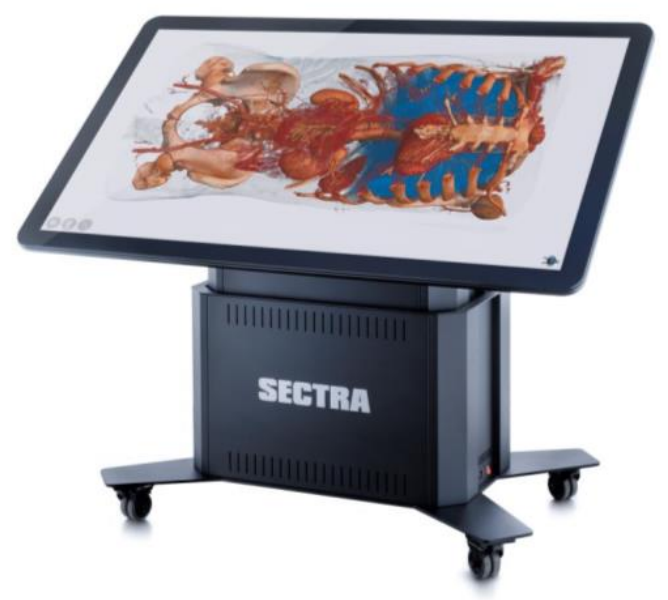

Figur 1. Sectra Table, venligst stillet til rådighed af Sectra AB Linköping

De tre grupper brugte i alt lige lang tid på at studere objektet. Testpersonernes anatomiske kundskaber blev efterfølgende målt ved en MC-test bestående af 50 spørgsmål. Studiet viste, at i den udstrækning testpersonerne selv kunne vælge, brugte de mest tid på at studere anatomien i vinkler, som lå tæt på det aksiale og det horisontale plan, selvom de havde mulighed for at vælge andre projektioner. Konklusionen blev, at disse planer således var vigtige for de studerendes indlæring (Garg et al., 2002). Studiet viste også, at der kun var minimale eller slet ingen fordele forbundet med at kunne orientere objektet i mange planer sammenlignet med små justeringsmuligheder tæt på det aksiale og det horisontelle plan. Man konstaterede desuden, at den enkelte studerendes individuelle evner i at tænke i forskellige planer havde betydning for indlæringen (Garg et al., 2002).

Formålet med dette projekt er derfor at foretage en kvantitativ måling af radiografstuderendes læring af abdominal 3D-anatomi ved simulering på Sectra Table med tilhørende software og sammenligne denne med læringsudbyttet ved traditionel anatomiundervisning indenfor samme anatomiske område.

\section{Metode}

UCN Rad har i begrænset omfang brugt simulering ved brug af Sectra Table i anatomiundervisningen af blandt andet abdomen siden 2016 ud fra et undervisningsprogram, som er blevet udviklet af uddannelsens anatomiundervisere. Undervisningen har hidtil foregået i grupper af maksimalt fire studerende. Hver gruppe har făet en introduktion til Sectra Table's funktioner af en anatomiunderviser. Efterfølgende har grupperne foretaget virtuelle dissektioner, hvor blandt andet abdomens anatomi er blevet visualiseret i $3 \mathrm{D}$.

Det overordnede design i dette studie var en baseline test efterfulgt af intervention samt test efter intervention (fig. 2). 


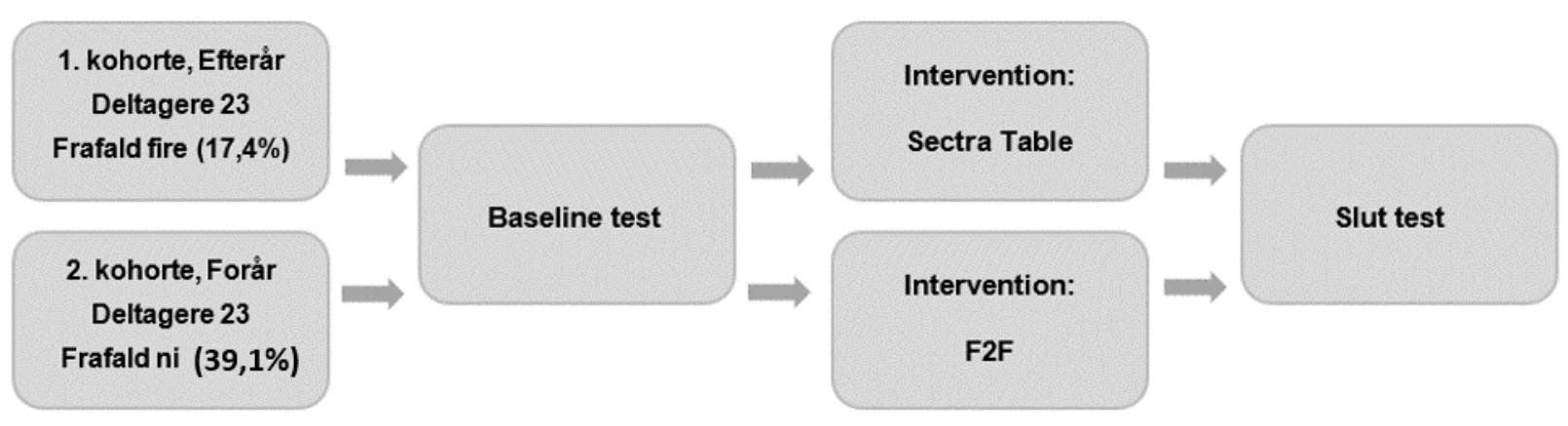

Figur 2. flowdiagram over processen

Baseline identifikation og testmålinger af en anatomisk struktur blev sammenlignet med en til formålet udarbejdet Gold standard. Gold standard var i udgangspunktet baseret på målinger udført af den underviser, som havde konstrueret testen. For at validere Gold standard gennemgik endnu en underviser fra projektgruppen testen og foretog de målinger, som testpersonerne senere skulle foretage. Disse målinger blev sammenlignet. Der, hvor der var afvigelser mellem de to målinger, blev endnu en måling foretaget af de to undervisere fra projektgruppen i fællesskab og Gold standard blev endeligt fastlagt.

De undervisere der stod for udførelsen af baseline test og test efter intervention, var blindet for interventionsindhold.

To kohorter udsættes for forskellige typer intervention. Afslutningsvis sammenlignedes ændringer i testresultaternes differencer mellem baseline- og opfølgningstest før og efter intervention mellem de to kohorter.

I dette projekt udgjorde to kohorter radiografstuderende på 3. semester den samlede studiepopulation. Ved UCN-rad optages et hold á 27 studerende hvert semester. Dataindsamling og intervention foregik derfor over to semestre, hvor holdet fra efterårssemesteret, 1 . kohorte, gennemgik intervention i form af et afgrænset forløb med undervisning i abdomens anatomi baseret på vejledning og simulering ved brug af Sectra Table. Dette forløb afvikledes i løbet af ugerne 35-40 2017. De studerendes viden om og forståelse af abdomens $3 \mathrm{D}$-anatomi blev testet før og efter intervention.

Holdet fra forårssemesteret, 2. kohorte, gennemgik intervention i form af et afgrænset undervisningsforløb i abdomens anatomi med traditionel holdundervisning. Undervisningens omfang svarende tidsmæssigt til simuleringstræningen for 1. kohorte. Forløbet afvikledes i løbet af ugerne 6-10 2018. Undervisningen bestod af traditionel face to face-undervisning. Dataindsamling fra begge kohorter var ens, og foregik i to faser, hvor de studerendes viden om og forståelse af abdomens $3 \mathrm{D}$ anatomi blev testet før og efter interventionen.

I den aktuelle periode (i begyndelsen af 3. semester) var både 1. kohorte og to hver især delt i 3 grupper grundet andre studieaktiviteter, som foregik parallelt med dataindsamlingen og interventionen ved dette projekt. Derfor blev dataindsamling og intervention gennemført i tre omgange i efterårs- og tre omgange i forårssemestret. Den enkelte studerende afviklede således et helt forløb, inklusive undervisning og tests, i løbet af én uge og den samlede dataindsamlings- og interventionsperiode varede 3 uger i efterårs- og tre uger i forårssemesteret.

Afslutningsvis sammenlignedes ændringer i testresultater før og efter intervention mellem 1. og 2 kohorte. 


\section{Udvælgelse af testpersoner}

Ifølge semesterbeskrivelsen for radiografuddannelsen retter 3. semester sig bl.a. mod at opnå et læringsudbytte om den menneskelige organismes normale anatomiske opbygning og fysiologiske funktion i relation til professionen.

De 3. semestersstuderende som udgjorde studiepopulationen havde fået en overordnet introduktion til abdomens anatomi på 1. semester. I forbindelse med den kliniske undervisning på 2. semester fik de et begrænset indblik i abdomens anatomi blandt andet i forbindelse med klinisk undervisning i CTskanning. CT-skanninger giver mulighed for at visualisere patienternes anatomi i forskellige planer og $\mathrm{i}$ 3D. I øvrigt havde de studerende ikke modtaget undervisning i abdomens anatomi og fysiologi.

Projektgruppen vurderede, at radiografstuderende på 3. semester havde et uddannelsesniveau som satte dem i stand til at gennemføre projektet samtidig med at kundskaberne indenfor abdomens $3 \mathrm{D}$-anatomi var så begrænset, at der fandtes et potentiale for forbedringer. Videre vurderede projektgruppen, at det var studierelevant for de studerende på 3. semester at deltage i et projekt om abdomens 3D-anatomi og, at testpersonerne fra henholdsvis 1 . og 2. kohorte havde et sammenligneligt uddannelsesniveau inden for området ved projektets begyndelse.

Begge kohorter var på 1. semester blevet introduceret til institutionens billeddatabase, som giver adgang til et stort billedmateriale fra forskellige undersøgelsesmodaliteter. Dog skiftede UCN Rad leverandør af billeddatabase i perioden mellem det at 1. og 2. kohorte blev interveneret og testet. Det billedmateriale, som blev anvendt til at teste testpersonernes viden om og forståelse af abdomens 3D-anatomi på 1 . kohorte, en nøje udvalgt CT-skanning af abdomen som tydeligt viste de relevante anatomiske strukturer, kopieredes over i den nye billeddatabase, som blev anvendt når 2. kohorte blev testet. De elektroniske værktøjer som testpersonerne havde til rådighed, når de gennemførte de to tests, var desuden stort set identiske i den gamle og den nye database.

I slutningen af 2. semester introduceredes begge kohorter til projektet, og den fulde projektbeskrivelse blev lagt ud på holdenes elektroniske undervisningsplatform for at give de studerende et fuldstændigt indblik i projektet. Projektgruppen vurderede, at dette kunne bidrage til at øge motivationen for at deltage i og gennemføre projektet samtidig med, at det også kunne have en læringsværdi i forhold til de projekter, de studerende selv skulle gennemføre senere i uddannelsen.

Alle dele af projektet, som involverede studerende, blev skemalagte. Testpersonerne skulle derfor ikke bruge tid udover skemalagt undervisningstid på at deltage i projektet.

\section{Inklusionskriterier}

Radiografstuderende på 3. semester ved UCN i Aalborg i efteråret 2017 eller i foråret 2018. Som tidligere nævnt udgjorde et helt hold radiografstuderende på 3. semester 1. kohorte. Det efterfølgende hold radiografstuderende på 3 . semester udgjorde 2 . kohorte.

Studerende på 1. og 2. kohorte inkluderedes i projektet, hvis de gennemførte alle projektets delelementer: Baseline test, deltagelse i samtlige vejlednings- og simuleringssessioner samt test efter intervention.

For at imødekomme krav i forhold til GDPR, underskrev de studerende samtykke for deltagelse, og samtlige testresultater var sikret anonymitet samt opbevaring efter gældende regler. 


\section{Eksklusionskriterier}

Studerende på 1. og 2. kohorte ekskluderedes, hvis de var fraværende fra et eller flere af projektets delelementer.

På 1. kohorte ekskluderedes i alt fire studerende ud af 23 (17,4 \%) af følgende årsager: Ej mødt: to studerende, sygdom: to studerende.

På 2. kohorte ekskluderedes i alt ni studerende ud af 23 (39,1 \%) af følgende årsager: Ej mødt: tre studerende, sygdom: seks studerende.

Dataindsamlingsperioden for 2. kohorte faldt sammen med en influenzaepidemi. Desuden blev området omkring Aalborg ramt af en snestorm som forhindrede et par studerende i at møde op. Det samlede frafald på 2. kohorte blev derfor meget højt.

\section{Effektmål}

Testpersonernes viden om og forståelse for abdomens $3 \mathrm{D}$-anatomi blev målt med udgangspunkt $\mathrm{i}$ en aksial, coronal og sagittal rekonstruktion af en CT-skanning af abdomen på en anonymiseret patient (fig. 3). Denne viden blev testet efter samme metode både før med en baseline test og efter interventionen med en afsluttende test identisk med baseline testen.
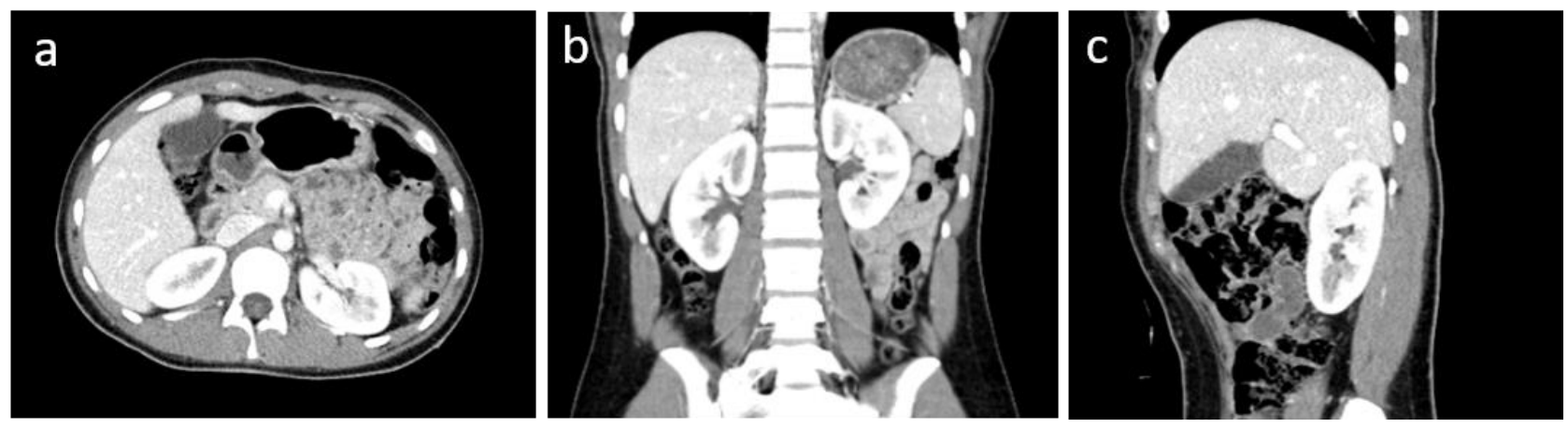

Figur 3. CT af abdomen med aksialt snit (a), coronalt snit (b) og sagittalt snit (c).

Testpersonens identifikation og målinger af en anatomisk struktur blev sammenlignet med Gold standard og bedømt i forhold til denne ud fra følgende kriterier:

Tabel 1. Point for identifikation af anatomisk struktur.

\section{Spm. a (Identifikation af en anatomisk struktur)}

\begin{tabular}{llll}
\hline & $\begin{array}{l}\text { Korrekt } \\
\text { identifikation }\end{array}$ & $\begin{array}{l}\text { Delvis korrekt } \\
\text { identifikation }\end{array}$ & $\begin{array}{l}\text { Forkert } \\
\text { identifikation }\end{array}$ \\
\hline \hline Point & 10 & 5 & 0 \\
\hline
\end{tabular}

En fuldt korrekt identificering af den efterspurgte anatomiske struktur udløste 10 points. Delvist korrekt identificering (f.eks. korrekt organ/struktur men forkert område af organet eller strukturen) udløste 5 points. Ingen eller forkert identificering af organet udløste o points (tabel 1). 


\section{Spm. b (Opmåling af en anatomisk struktur)}

Tabel 2. Point for opmåling af anatomisk struktur i forhold til afvigelser i mm fra Gold standard.

\begin{tabular}{|c|c|c|c|c|c|c|c|c|c|c|c|}
\hline Afvigelse mm & $\leq 1$ & $\leq 2$ & $\leq \mathbf{3}$ & $\leq 4$ & $\leq 5$ & $\leq 6$ & $\leq 7$ & $\leq \mathbf{8}$ & $\leq 9$ & $\leq 10$ & $\geq \mathbf{1 1}$ \\
\hline Point & 10 & 9 & 8 & 7 & 6 & 5 & 4 & 3 & 2 & 1 & o \\
\hline
\end{tabular}

Hvis testpersonens måling lå indenfor $\pm 1 \mathrm{~mm}$ fra Gold standard, udløste dette 10 points. Hvis afvigelsen var større end $1 \mathrm{~mm}$, blev 1 point trukket fra de maksimale 10 for hver mm testpersonens måling afveg fra Gold standard. En afvigelse på 11 mm eller mere udløste således o points (tabel 2).

Testen kunne maksimalt udløse 200 points. Der var afsat en lektion á 45 minutter til gennemførelsen af den indledende øvelse og den efterfølgende test. Samtlige testpersoner gennemførte øvelse og test inden for denne tidsfrist.

\section{Interventioner}

\section{Forberedelse}

Iflg. Semesterbeskrivelsen for 3. semester skulle de studerende på begge kohorter forberede sig til undervisningen ved at læse pensum i ernæring, fordøjelse og stofskifte i anbefalede lærebog (Nielsen \& Springborg, 2005). Projektgruppen førte ikke kontrol over den enkelte studerendes forberedelse, altså hvor mange af testpersonerne som faktisk læste litteraturen forud for undervisningen, hvor meget de læste eller hvor meget de i øvrigt læste på emnet i løbet af projektperioden. Forventningerne til de studerendes forberedelse var dog de samme for 1. og 2. kohorte.

\section{Sectra Table undervisning for 1 . kohorte}

\section{Undervisningsform}

\section{Instruktion}

1. kohorte blev inddelt i grupper på to til fire studerende. Grupperne blev instrueret i brugen af Sectra Table i én lektion á 45 minutter. Instruktionerne blev varetaget af et af projektgruppens medlemmer, som er underviser i anatomi og som desuden har et grundigt kendskab til funktionerne i Sectra Table. (Samme underviser varetog al træning og vejledning af 1 . kohorte samt al face to face undervisning af 2. kohorte.) Testpersonerne i 1 . kohorte blev primært instrueret i de for projektet relevante funktioner ved Sectra Table. Formålet med instruktionen var, at testpersonerne skulle opnå grundlæggende praktiske færdigheder i brugen af bordet. Instruktioner og eksempler blev givet ud fra billedmateriale baseret på en CT-skanning, hvor man benyttede aksiale, coronale og sagittale rekonstruktioner, samt en helkrops 3D rekonstruktion af Virtual Human (VH) (fig. 4) baseret på en krop fra en afdød.

\section{Individuel træning under vejledning}

Hver testperson foretog en virtuel dissektion af VH ved Sectra Table af en lektions varighed under individuel vejledning. Vejledningen bestod af hjælp til brugen af Sectra Table samt vejledning/undervisning i abdomens $3 \mathrm{D}$ anatomi. Formålet var at opnå: 
1. Grundlæggende praktiske færdigheder i brug af bordets software.

2. Færdigheder i at identificere organer i øvre abdomen.

3. Forståelse for organernes præsentation $\mathrm{i}$ henholdsvis $2 \mathrm{D}$ og $3 \mathrm{D}$.

4. Forståelse for organernes lokalisation i forhold til omkringliggende strukturer i tre dimensioner og disses indbyrdes relationer.

Én af dissektionsopgaverne lød:

"Fjern glandulae suprarenales. Orienter dig om de forskellige blodkar til renes og deres orientering i forhold til hinanden. Venae renales tømmer sig i en stor vene. Hvilken? Hvilket forløb giver dette anledning til på henholdsvis højre og venstre side?"

Træningen blev planmæssigt gennemført for alle inkluderede testpersoner.

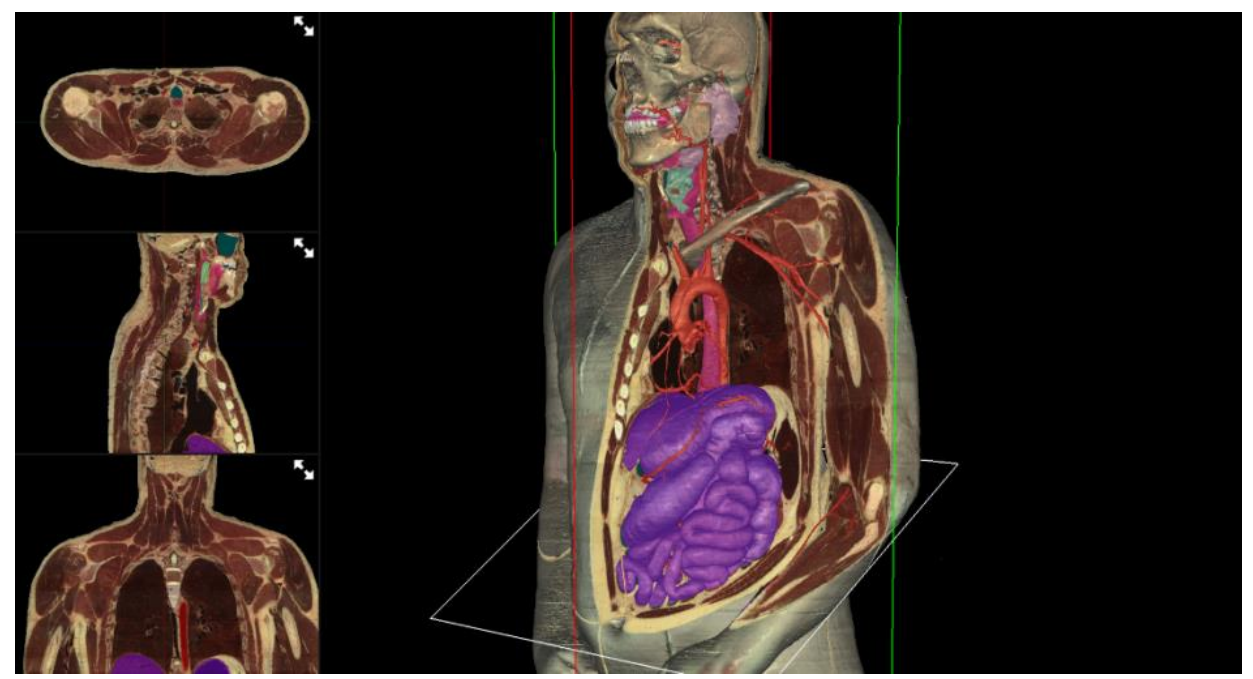

Figur 4. Virtual Human Dissector, venligst stillet til rådighed af ToLTech inc.

\section{Parvis træning med vejledning}

To testpersoner dissekerede i fællesskab virtuelt VH ved Sectra Table i totalt en lektion under vejledning. Formålet med træningen var, at testpersonerne skulle opnå færdigheder i at identificere organer i øvre abdomen, få en øget forståelse for organernes præsentation i 3D samt en øget forståelse for organernes lokalisation og indbyrdes relationer til omkringliggende strukturer. Den af testpersonerne, som ikke aktuelt var beskæftiget med den virtuelle dissektion, assisterede den anden testpersons forsøg på identifikation af anatomiske strukturer med udgangspunkt i et anatomisk atlas. Vejlederen trådte til der, hvor testpersonerne havde brug for hjælp i forhold til anatomi eller bordets funktioner.

Træningen blev planmæssigt gennemført for alle inkluderede testpersoner.

Træningsformen blev valgt på baggrund af tidligere positive erfaringer med Peer learning ved UCN-rad, men også som beskrevet af Fogstad \& Christiansen (Fogstad \& Christiansen, 2011).

Ved Peer Learning sammensættes grupper af individer, som skal lære. Individerne skaber mening, definerer og løser problemer hver især. Den sociale kontekst støtter op om og forstærker disse processer (O’ Donnell \& King, 1999).

\section{Parvis træning uden vejledning}

To testpersoner dissekerede i fællesskab virtuelt VH ved Sectra Table i totalt en lektion uden yderligere instruks. Der var ikke krav om dokumentation bortset fra at deltagelsen dokumenteredes ved underskrifter på dokumentationsark. Projektgruppen vurderede, at testpersonerne nu havde et 
tilstrækkeligt kendskab til Sectra Table's funktioner samt den grundlæggende $3 \mathrm{D}$-anatomi til, at man var i stand til selvstændigt at gennemføre virtuel dissektionstræning. Formålet med træningen var, at testpersonerne skulle opnå færdigheder i at identificere organer i øvre abdomen, få en øget forståelse for organernes præsentation i 3D samt en øget forståelse for organernes lokalisation og indbyrdes relationer til omkringliggende strukturer. Den af testpersonerne, som ikke aktuelt var beskæftiget med den virtuelle dissektion, skulle ligesom tidligere assistere den anden testpersons forsøg på identifikation af anatomiske strukturer med udgangspunkt $i$ et anatomisk atlas.

Iflg. Dokumentationsarket blev træningen planmæssigt gennemført af alle inkluderede testpersoner.

\section{Face to Face undervisning for 2. kohorte}

\section{Undervisningsform}

\section{Face to Face}

2. kohorte modtog undervisning i abdomens anatomi i form af face to face-undervisning. Den samlede undervisningstid var fem lektioner, hvilket timemæssigt svarede til undervisningen af 1 . kohorte ved Sectra Table.

Undervisningsformen var forelæsning med mulighed for dialog. Undervisningsform og materiale var løbende blevet udviklet af underviseren gennem mere end ti års anatomiundervisning ved UCN Rad. Undervisningen blev understøttet af Power Point slides med en begrænset mængde tekst samt anatomiske tegninger, CT-billeder og konventionelle røntgenbilleder. Alt billedmateriale præsenteredes i 2D. Ved behov blev dette materiale suppleret med tegninger på tavlen.

\section{Selvstudie}

Ud over pensumlitteraturen havde underviseren lagt fjorten læringsspørgsmål i form af afkrydsningsspørgsmål, med IT-baseret (automatiseret) bedømmelse, som testpersonerne kunne udfylde, samt yderligere 40 studiespørgsmål som blev lagt på holdets elektroniske læringsplatform af underviseren.

\section{Statistik}

\section{Databearbejdning}

Data blev indtastet og analyseret i MS Excel Version 2012 (Build 13519.20000). Ved normalfordeling blev kontinuerte data beskrevet med middelværdi og standard deviation (SD). Forskel mellem baseline test og den opfølgende test samt disse middelværdiers differencer blev testet med en t-test. Der blev anvendt et signifikansniveau på $5 \%$. 


\section{Resultater og analyse}

\section{Hele testen}

De 19 inkluderede studerende på 1. kohorte, som senere gennemgik intervention i form af et afgrænset forløb med undervisning i abdomens anatomi baseret på vejledning og simulering ved brug af Sectra Table. Kohorterne opnåede følgende antal points (p.) før og efter intervention (tabel 3), hvor der maksimalt kunne opnås 200 p.:

Tabel 3. Samlede antal point før og efter intervention af 1 . kohorte inkl. middelpoint, SD og procentvis ændring. (*) negativ score skyldes studerende, der klarede sig dårligere i sluttest end i baseline test

\begin{tabular}{lccc}
\hline 1. kohorte: & Middel point (SD) & Minimum point & Maximum point \\
\hline Baseline test & $109,1(34,4)$ & 39 & 149 \\
Test efter intervention & $147,7(20,5)$ & 119 & 195 \\
\hline & Middel point (SD) & Point (min / max) & $\%$ \\
\hline Endring & $38,6(23,7)$ & $-1\left(^{*}\right) / 86$ & 35,4
\end{tabular}

De 13 inkluderede studerende på 2. kohorte, som senere gennemgik intervention i form af et afgrænset undervisningsforløb i abdomens anatomi med traditionel holdundervisning, opnåede følgende resultater før og efter intervention:

Tabel 4. Samlede antal point før og efter intervention af 2. kohorte. inkl. middelpoint, SD og procentvis ændring

\begin{tabular}{lccc}
\hline 2. kohorte: & Middel point (SD) & Minimum point & Maximum point \\
\hline Baseline test & $116,2(28,5)$ & 54 & 147 \\
Test efter intervention & $143,2(17,0)$ & 105 & 160 \\
\hline & Middel point (SD) & Point (min / max) & $\%$ \\
\hline Endring & $27(21,1)$ & $3 / 71$ & 23,2 \\
\hline
\end{tabular}

Som det fremgår af ovenstående tabel 4, scorede 2. kohorte i gennemsnit 7,1 p. (6,5\%) højere i baseline testen end 1. kohorte. Testpersonerne på 1. kohorte forbedrede sig i gennemsnit med 35,4\%. Forbedringen blandt testpersonerne på 2. kohorte var i gennemsnit 23,2\%.

Den gennemsnitlige forbedring var således $12,2 \%$ større for testpersonerne på 1. kohorte end for testpersonerne på 2. kohorte (35,4 vs. 23,2). Forskellene i, hvor meget 1. og 2. kohorte forbedrede sig i forhold til hinanden, var dog ikke statistisk signifikante $(\mathrm{p}=0,16)$.

Som nævnt i metodeafsnittet var de 10 opgaver i testen opdelt i to underspørgsmål (a og b), hvor hensigten med a-spørgsmålene var at kvantificere de studerendes færdigheder i at identificere anatomiske strukturer. Hensigten med b-spørgsmålene var at kvantificere de studerendes færdigheder i at måle udvalgte anatomiske strukturer ved hjælp af billeddatabasens elektroniske måleværktøj. Testpersonernes færdigheder i at måle anatomiske strukturer blev dog ikke øvet i forbindelse med interventionen, hverken for 1. eller 2. kohorte. Alligevel var hovedfokus ved b-spørgsmålene netop at udføre målinger. På grund af dette har vi i det følgende valgt at redegøre for resultaterne fra a- og bspørgsmålene hver for sig.

\section{A-spørgsmålene (identificering af anatomiske strukturer)}

De inkluderede studerende på 1. kohorte opnåede følgende antal p. ved a-spørgsmålene (tabel 5), identificering af anatomiske strukturer, før og efter intervention hvor man maksimalt kunne opnå 100 p.: 
Tabel 5. Point for identificering af anatomisk struktur (a-spørgsmål) før og efter intervention af 1. kohorte inkl. middelpoint, SD og procentvis ændring.

\begin{tabular}{|c|c|c|c|}
\hline 1. kohorte: & Middel point (SD) & Minimum point & Maximum point \\
\hline \multirow{3}{*}{$\begin{array}{l}\text { Baseline test } \\
\text { Test efter } \\
\text { intervention }\end{array}$} & $56,1(19,9)$ & 20 & 90 \\
\hline & $83,2(12,4)$ & 55 & 100 \\
\hline & Middel point (SD) & Point (min / max) & $\%$ \\
\hline Endring & $27,1(12,8)$ & $5 / 45$ & 48,3 \\
\hline
\end{tabular}

Studerende på 2. kohorte opnåede følgende antal p. ved a-spørgsmålene (tabel 6), identificering af anatomiske strukturer, før og efter intervention hvor man maksimalt kunne opnå 100 p.:

Tabel 6. Point for identificering af anatomisk struktur (a-spørgsmål) før og efter intervention af 2. kohorte inkl. middelpoint, SD og procentvis ændring.

\begin{tabular}{lccc}
\hline 2. kohorte: & Middel point (SD) & Minimum point & Maximum point \\
\hline Baseline test & $57,3(16,3)$ & 35 & 80 \\
Test efter & $80,0(37,7)$ & 55 & 95 \\
intervention & Middel point (SD) & Point (min / max) & $\%$ \\
\hline Endring & $27,7(9,0)$ & $10 / 40$ & 39,6 \\
\hline
\end{tabular}

Også her opnåede 2. kohorte et højere gennemsnit end 1. kohorte. Forskellen var dog kun 1,2 p. (2,1\%).

Testpersonerne på 1. kohorte forbedrede sig i gennemsnit med 48,3\%. Forbedringen blandt testpersonerne på 2. kohorte var i gennemsnit 39,6\%.

Den gennemsnitlige forbedring ved a-spørgsmålene (identificering af anatomiske strukturer), hvor man maksimalt kunne opnå 100 p., var her 4,4 p. (8,7\%) større for testpersonerne på 1. kohorte end for testpersonerne på 2. kohorte (48,3 vs. 39,6). Forskellene i, hvor meget 1. og 2. kohorte forbedrede sig i forhold til hinanden, var dog ikke statistisk signifikante $(\mathrm{p}=0,26)$

\section{B-spørgsmålene (måling af udvalgte anatomiske strukturer)}

De inkluderede studerende på opnåede følgende antal p. ved b-spørgsmålene, måling af udvalgte anatomiske strukturer, før og efter intervention (tabel 7) hvor man maksimalt kunne opnå 100 p.:

Tabel 7. Point for måling af anatomisk struktur (b-spørgsmål) før og efter intervention af 1. kohorte inkl. middelpoint, SD og procentvis ændring. $\left.{ }^{*}\right)$ negativ score skyldes studerende, der klarede sig dårligere i sluttest end i baseline test.

\begin{tabular}{|c|c|c|c|}
\hline 1. kohorte: & Middel point (SD) & Minimum point & Maximum point \\
\hline \multirow{3}{*}{$\begin{array}{l}\text { Baseline test } \\
\text { Test efter } \\
\text { intervention }\end{array}$} & $53,1(17,1)$ & 19 & 78 \\
\hline & $64,5(12,0)$ & 44 & 95 \\
\hline & Middel point (SD) & Point (min / max) & $\%$ \\
\hline Endring & $11,5(16,1)$ & $-16(*) / 43$ & 21,5 \\
\hline
\end{tabular}

Studerende på 2. kohorte opnåede følgende antal p. ved b-spørgsmålene (tabel 8), identificering af anatomiske strukturer, før og efter intervention hvor man maksimalt kunne opnå 100 p.: 
Tabel 8. Point for måling af anatomisk struktur (b-spørgsmål) før og efter intervention af 2. kohorte inkl. middelpoint, SD og procentvis ændring. $(*)$ negativ score skyldes studerende, der klarede sig dårligere i sluttest end i baseline test

\begin{tabular}{lccc}
\hline 2. kohorte: & Middel point (SD) & Minimum point & Maximum point \\
\hline $\begin{array}{l}\text { Baseline test } \\
\text { Test efter } \\
\text { intervention }\end{array}$ & $58,9(14,6)$ & 19 & 72 \\
\hline & $63,2(10,9)$ & 49 & 80 \\
\hline Endring & Middel point (SD) & Point (min / max) & $\%$ \\
\hline
\end{tabular}

Her scorede 2. kohorte i gennemsnit 5,8 p. (10,9\%) højere i baseline testen end 1. kohorte.

Testpersonerne på 1. kohorte forbedrede sig i gennemsnit med 21,5\%. Ændringen blandt testpersonerne på 2. kohorte var i gennemsnit 7,3\%.

Den gennemsnitlige forbedring ved b-spørgsmålene (måling af udvalgte anatomiske strukturer), hvor man maksimalt kunne opnå 100 p., var her 7,1 p. (14,2\%) større for testpersonerne på 1. kohorte end for testpersonerne på 2. kohorte (21,5 vs. 7,3$)$. Forskellene i, hvor meget 1. og 2. kohorte forbedrede sig i forhold til hinanden, var dog ikke statistisk signifikante $(\mathrm{p}=0,18)$.

\section{Diskussion}

Som det fremgår af resultatafsnittet, scorede 2. kohorte generelt bedre ved baseline tests end 1. kohorte. For testen som helhed (a- og b- spørgsmål tilsammen) var differencen mellem de to kohorter 7,1 p.

I og med at testen havde en maksimumsgrænse (200 p.), havde 2. kohorte i udgangspunktet et mindre potentiale for forbedringer sammenlignet med 1. kohorte. Det vides ikke med sikkerhed, hvilken betydning dette har haft $\mathrm{i}$ forbindelse med at forbedringerne mellem baseline test og test efter intervention (som et resultat af interventionerne) er blevet sammenlignet mellem de to kohorter.

På 1. kohorte, hvor interventionen bestod af et afgrænset forløb med undervisning i abdomens anatomi baseret på vejledning og simulering ved brug af Sectra Table, sås der en tendens til at forbedre sig pointmæssigt mere end 2. kohorte, hvor interventionen bestod af et afgrænset undervisningsforløb med traditionel holdundervisning. Dette gjorde sig gældende ved samtlige parametre (a-spørgsmål, bspørgsmål og den samlede test). Dog var forskellene i forbedring mellem 1. kohorte og 2. kohorte ikke statistisk signifikante på nogen af de tre parametre. Den mest åbenlyse forklaring på dette er, at forskellen i hvor meget de studerende lærer ved den ene eller den anden undervisningsmetode, er lille eller slet ikke eksisterende. Denne forklaring stemmer godt overens med resultaterne fra studiet af Garg et al., som kun påviste minimale eller slet ingen fordele ved at de medicinstuderende kunne orientere objektet i mange planer ved indlæringsprocessen (Garg et al., 2002).

Uanset hvad eventuelle kommende studier måtte vise, vil undervisning ved hjælp af Sectra Table ikke kunne stå alene ved undervisning i anatomi og fysiologi af den simple grund at udstyret kun er velegnet til anatomiundervisning. Fysiologiundervisningen må fortsat gennemføres på en anden måde.

I forbindelse med dette projekt blev Sectra Table brugt systematisk i et undervisningsforløb for første gang ved UCN-rad. Undervisningsmetoden var ved projektets start og gennemførelse uprøvet og sandsynligvis ikke færdigudviklet. Det kan derfor anses for at være en begrænsning i projektet, og dermed kunne det medføre usikkerhed i de studerende læring. Undervisningen ved Sectra Table var også kendetegnet ved et stort ressourceforbrug da vejledning og træning til dels blev afviklet som individuel træning, med én underviser og én studerende, til dels i små grupper. En del af træningen afvikledes dog som træning i større grupper, som en form for peer learning, uden at en underviser var til stede. Ved et længere undervisningsforløb ville denne undervisningsform muligvis kunne udgøre en 
større del af den samlede undervisningspakke og på den måde nedbringe forbruget af undervisertimer til et niveau svarende til traditionel holdundervisning.

I øvrigt kan vores metode kritiseres for, at samme billedmateriale anvendes i forbindelse med baseline test og test efter intervention, da der foreligger en risiko for, at testpersonerne kan genkende og huske billedmaterialet fra baseline testen når de gennemfører test efter intervention. Dette var ens for begge kohorter, og må antages at påvirke disse ens. Metoden er valgt for at undgå effekter med baggrund i forskelligheder i billedmaterialet $\mathrm{i}$ form af patologi, normalvariationer, varierende adipositas og billedkvalitet etc., hvilket vil kunne tænkes at påvirke testresultaterne.

Der blev ikke til dette studie indsamlet demografiske data, da det var projektgruppens vurdering, at 1. kohorte og 2. kohorte har haft samme betingelser på dette punkt, da de studerende på 3. semester har opnået en fælles faglig baggrund, selvom køn og etnicitet er forskellig, og dette burde derfor ikke påvirke projektets validitet i forhold til at sammenligne de to undervisningsmetoder.

De undervisere, der stod for baseline test og slut test var blindede i forhold til indhold af interventionerne. Ligeledes var den underviser der stod for interventionerne blindet i forhold til indhold i baseline test og slut test. Denne underviser er dermed elimineret som en mulig bias i forhold til, om testen kunne være en valid parameter i forhold til det reelle læringsudbytte som testen var designet til at måle.

UCN Rad skiftede leverandør af billeddatabase i perioden mellem afviklingen af 1. kohorte og 2. kohorte. Det billedmateriale som blev anvendt, kopieredes over i den nye billeddatabase, som 2. kohorte blev testet efter. Det blev konstateret, at de elektroniske værktøjer som testpersonerne havde til rådighed, når de gennemførte de to tests, i det store hele var identiske i den gamle og den nye database. Det er derfor projektgruppens vurdering, at studiets resultater ikke er blevet påvirket af leverandørskiftet i væsentlig grad.

Desuden findes der faktorer i dette projekt som har stået uden for projektgruppens kontrol. F.eks. har det været umuligt at kontrollere, hvor meget testpersonerne på de to kohorter har læst eller i øvrigt øvet sig udenfor skemalagt undervisningstid, og om det har været forskelle mellem de to kohorter på dette punkt. Dette kan virke som en confounder, hvilket kan have medført, at den relativ lille forbedring skyldtes, at 2. kohorte selvstændigt havde øvet sig mere end 1. kohorte.

\section{Konklusion}

Dette studie har ikke kunnet dokumentere, at Sectra Table fører til hverken bedre eller dårligere resultater når studerende skal lære $3 \mathrm{D}$-anatomi.

Undersøgelsen har ikke påvist statistisk signifikant forskel i forhold til radiografstuderendes læring af abdominal 3D-anatomi ved simulering på Sectra Table med tilhørende software sammenlignet med læringsudbyttet ved traditionel anatomiundervisning indenfor samme anatomiske område. Disse resultater stemmer godt overens med erfaringer fra tidligere studier (Garg et al., 2002).

Der ses en tendens i retning af en mindre fordel ved brug af Sectra Table, og Sectra Table kan derfor anses for at have et muligt udviklingspotentiale som supplement til traditionel undervisning.

Den begrænsede datamængde i dette studie betyder dog, at problemstillingen bør undersøges yderligere, både for at opnå mere valide resultater, men også med henblik på at optimere undervisningsmetoderne dér, hvor Sectra Table bliver brugt. 


\section{Referencer}

Dougherty, G. (2009). Digital image processing for medical applications. Cambridge University Press.

Fogstad L, Christiansen B. (2011) Moving the Boundaries: Peer Learning between Nursing and Physiotherapy Students. Vård i Norden 3.

Garg, A., Norman, G., Eva, K., Spero, L., Sharan, S. (2002). Is There Any Real Virtue of Virtual Reality?: The Minor Role of Multiple Orientations in Learning Anatomy from Computers. Academic Medicine, volume 77, No. 10.

Lundström, C., Rydell, T., Forsell, C., Persson, A., Ynnerman, A. (2011). Multi-touch Table System for Medical Visualization: Application to Orthopedic Surgery Planning. IEEE Transactions on Visualization and Computer Graphics, volume: 17, issue: 12.

Nielsen, O. \& Springborg, A. (2005). Ind under huden, anatomi og fysiologi. 2. udg., 3 oplag Munksgaard, København.

O’ Donnell AM, King A. (1999). Cognitive perspectives on peer learning. Lawrence Erlbaum Associates Inc., Mahwah, NJ.

Sectra AB, https://sectra.com/medical/product/sectra-terminals/ (lokaliseret 20.09.2018).

\section{Forfattere}

\section{Michael Ehrnberg Fravn}

Lektor, B.Sc.

University College Nordjylland

\section{Jens Kristian Vejle-Sørensen}

Lektor, Master in Health Informatics

University College Nordjylland

\section{Lars-Göran Zetterberg}

Lektor, Master in Radiography
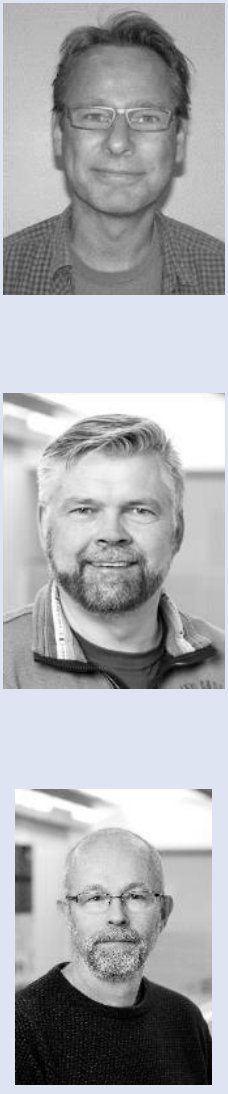